\title{
THE PHENOMENON OF THE CONCILIAR REFORM OF THE RITES OF THE CONSECRATION OF VIRGINS
}

DOI: http://dx.doi.org/10.12775/TiCz.2019.040

\begin{abstract}
It is little known that there is a consecration of secular women in the Church, that is a special liturgical ceremony or rite, during which the woman promises that she will live in eternal purity for the Kingdom of God. The Church's intention is to make this ceremony primarily for women who are not associated in any institutions or communities, and who live individually and lead a secular lifestyle. The condition to admit the woman to this ceremony by the bishop is that the woman did not marry or not live in a state opposite to chastity. The whole novelty of current ceremonies is expressed in the admission to the consecration of secular virgins who remain in the secular world and carry out their professional and social work. Eight centuries after the dropping of the practice of the consecration of secular virgins, the Church, guided by the spirit of the times, returns to its old tradition and restores the rite of consecration to "their original owners", that is secular women. Renewed ceremonies of consecration can be seen as a special expression of respect for a woman whose dignity is sometimes offended by a society dominated by myths of hedonism and consumption. The author deals with the diocesan identity and character of the class or status of virgins as being typical for this form of consecrated life. In addition, he raises issues related to the conditions of admitting the women to consecration, the theological assumptions of the rite and the form of its celebration.
\end{abstract}

Keywords: consecration; virginity; liturgy; reform; betrothal; marriage/nuptials. 
Streszczenie. Fenomen soborowej reformy obrzędów konsekracji dziewic. Mało znany jest fakt, że w Kościele istnieje konsekracja kobiet świeckich, czyli specjalny obrzęd liturgiczny, podczas którego kobieta składa przyrzeczenie, że będzie żyła w dozgonnej czystości dla Królestwa Bożego. W zamyśle Kościoła obrzęd ten przeznaczony jest przede wszystkim dla kobiet niezrzeszonych w żadnych Instytutach ani wspólnotach, ale żyjących indywidualnie i prowadzących świecki tryb życia. Warunkiem dopuszczenia do tego obrzędu przez biskupa jest to, że kobieta nie zawarła małżeństwa ani nie żyła w stanie przeciwnym czystości. W dopuszczeniu do konsekracji dziewic świeckich, pozostających w świecie i wykonujących swoje prace zawodowe i społeczne, wyraża się cała nowość obecnych obrzędów. Po ośmiu wiekach od czasu zaprzestania praktyki konsekracji dziewic świeckich Kościól, kierowany duchem czasu, wraca do swojej dawnej tradycji i przywraca obrzęd konsekracji „ich pierwotnym właścicielom”, czyli kobietom świeckim. Można odnowione obrzędy konsekracji uznać za szczególny wyraz szacunku dla kobiety, której godność jest niekiedy obrażana przez społeczność zdominowaną mitami hedonizmu i konsumpcji. Autor zajmuje się tożsamością i charakterem diecezjalnym stanu dziewic jako typowym dla tej formy życia konsekrowanego. Porusza ponadto zagadnienia związane z warunkami dopuszczenia kobiet do konsekracji, założeniami teologicznymi obrzędu oraz formą jego sprawowania.

Słowa kluczowe: konsekracja; dziewictwo; liturgia; reforma; oblubieńczość; zaślubiny.

The new rites of the consecration of virgins, forming an integral part of the Roman Pontifical ${ }^{1}$ published on the Nativity of the Blessed Virgin Mary, on $8^{\text {th }}$ September 1970, should be described as a phenomenon, because after several centuries, the Church restores the ceremonies of consecration to their original owners, that is, the women living in the secular world and who want to devote their lives to virginity.

All the newness of the present ceremony is expressed in allowing the secular virgins who remain in the world and carry out their professional and social work to be consecrated. Eight centuries after the dropping of the practice of the consecration of secular virgins ${ }^{2}$, the Church,

${ }^{1}$ Pontificale Romanum ex decreto Sacrosancti Oecumenici Concilii Vaticani II auctoritate Pauli pp. VI promulgatum, Ordo Consecrationis Virginum, Editio typica, Typis Polyglottis Vaticanis 1970 (I guote briefly from here OCV).

2 The consecration of secular virgins was universally prohibited at the Second Lateran Council (1139); Mansi 21, 527-528, can. 7-8. 
guided by the spirit of the times, returns to its old tradition and restores the ceremony of the consecration to the secular women. Thus, after eight centuries, the Church revives the virgin status again and, having adapted its spiritual dimension to the specific circumstances of our time ${ }^{3}$, gives it as a gift to the local community so that it can grow and mature in its supernatural nature. In the post-synodal exhortation of John Paul II Vitaconsecrat, the latest document devoted to consecrated life, we read: "It is joyful and hopeful that the ancient state or status of virgins devoted to God, whose existence in Christian communities has been confirmed since apostolic times, is being out once again. Virgins consecrated by the bishop unite especially with the local Church, which they serve with dedication, although they remain in the world. Living alone or together with others, they are a special eschatological image of the heavenly Bride and future life in which the Church will finally experience the full love of Christ the Bridegroom." 4 The decision of the Holy See regarding the extension of Ordo reveals, therefore, "the eternal youth of the Church" ${ }^{5}$ which is able to extract old things from its spiritual treasury and make them new.

The promulgation of this liturgical book is undoubtedly an act of faith of the Church in the message of Christ and its faith in the supernatural value of consecrated virginity accomplished by the power or authority of the Holy Spirit. The whole context and social climate in which it takes place today is very similar to the reality of the ancient world in which the ideal of Christian virginity was born and shaped. The Church recognizes again its important dimension of the consecrated virginity testimony to the kingdom of God in our era in which the whole culture, permeated with sensuality and showing little in common with the Gospel message, does not understand, contests and mocks the mystery of life in virginity. This fact deserves even more emphasis since the Church does this by noticing and appreciating the significance of virginity experienced in typically secular conditions, outside the structures of religious life and the

${ }^{3}$ Synod Biskupów. IX Zgromadzenie Zwyczajne, Życie zakonne i jego posłannictwo $w$ Kościele $i$ świecie. Instrumentum laboris, Watykan 1994, 34. Synod of Bishops. IX Ordinary Assembly, Religious life and his mission in the Church and the world. Instrumentum laboris, Vatican 1994, 34.

4 John Paul II, Post-Synodal Papal Exhortation: Vita consecrata, AAS (1996) 7.

${ }^{5}$ Ibidem, 12. 
walls of the monasteries, and which is sanctioned by the most prominent liturgical act of the Church, which is the ceremony of bridal, christological and ecclesial consecration. ${ }^{6}$

Therefore, renewed ceremonies of consecration can be considered a special expression of respect for a woman whose dignity is sometimes offended by the society dominated by myths of hedonism and consumption. Renewed rites want to restore her proper position in today's society, as well as in the community of the Church. They are the testimony of the beneficial processes that are taking place in this field, as well as the extremely important fact that a return to the spiritual attitude of the original Church does not necessarily mean a return to anachronism. ${ }^{7}$

\section{A BRIEF HISTORICAL OUTLINE OF THE CONSECRATION}

Church writers of the second and the third century testify how, in various Christian communities, the ideal of virginity, which was rooted in the example of Jesus and His Mother, constantly found new followers and expressed himself in taking the vow of virginity. However, this vow was private, not public. This means that it was not taken in facie Ecclesiae, that is in a liturgical setting. Women who took it were, however, recognized by the environment as people forming a special group of the faithful, i.e. the state of virgins (ordo virginum). Because of their special calling, they devoted themselves to God's worship and work of mercy. The first testimony of a special ceremony of the virgin consecration, i.e. public vow of virginity and solemn blessing of the Church, comes from the middle of the 4 th century.

The Pope Liberius (352-365), with the numerous participation of the believers, carried out or imparted the ceremony of consecration of Marcellina, sister of St. Ambrose at St. Peter's Basilica in Rome during the Epiphany in $352 .{ }^{8}$ At the end of the 4 th century, the ceremonies of con-

${ }^{6}$ I.M. Calabuig, R. Barbieri, Consacrazione delle vergini, w: Nuovo Dizionario Liturgico (I guote briefly from here NDL), Roma 1984, 300-301.

7 B. Kleinheyer, Celebrazioni sacramentali - I riti di ammisione alla Chiesa, w: La liturgia della Chiesa. Manuale di scienza liturgica, vol. 9, Torino 1994, 271.

8 Ambroży, De virginibus, 1; PL 16, 231-233. 
secration of the virgins are already quite widely celebrated in the Western Church. This is confirmed by Saint Ambrose, who writes: "The Passover is coming: the sacrament of baptism is celebrated and the ceremony of virgin consecration is carried out in the entire Christian world."

It should be noted that, apart from purely supernatural motives, the very social situation of the woman and her place in ancient society contributed to the development of this form of spiritual life. As it is well known - she was never sui iuris. At every stage of her life she was dependent on a man; as a girl she was in manupatris, as a married woman she was subject to her husband's authority, as a widow she had to give way to her eldest son in the home hierarchy. The moral decline of the pagan community made the situation of a woman worse, making her an object of pleasure. The process of the decline of moral values first affected a woman, causing that she lived in humiliation and degradation, and her activities, except for a few exceptions, were limited to ordinary housework. It is true that historians testify to certain Hellenic and Roman emancipation during the Hellenic-Roman era, but that only applied to a very narrow group of women. Among Christian communities, faith in Christ and love of neighbor may, however, give rise to new quality in interpersonal relations, fraternizing pagans with Jews, masters with slaves, men with women, but the social structures themselves remain unchanged: a woman is subject to a man, children to the father, slaves to the master (see Kol 3, 19-22). ${ }^{10}$ So from the socio-cultural perspective, choosing a way of life in single blessedness put a woman in a completely different situation. It seems that the Christian virgin had more autonomy and she more decisively made a choice, touching the very depth of her life, than other women could have done in choosing their life partner. ${ }^{11}$ In addition, taking the path of life in virginity made her free from all family and social conditions, and in the future it sometimes allowed her to fulfill her life aspirations in a better way. ${ }^{12}$ Later, when the vow of virgin

9 Ambroży, Exhortatio virginitatis, 7, 42: Venit Paschae, in toto orbe baptism isacramenta celebrantur, velantur sacrae virgines; PL 16, 364.

${ }^{10}$ Cf. G. Tosetti, Vergini consacrate nel mondo. Un rito alle origini, Bologna 1990, 69-71.

11 Cf. ibidem, 69-71.

${ }^{12}$ Cf. P. Visentin, Genesi e sviluppo storico-culturale della consecrazione veriginale, 
is confirmed by a solemn consecration, the woman as virgo Christi will report directly to the bishop and will remain under the protection of the Church. ${ }^{13}$ Therefore, in the ceremony of the consecration of virgins one should notice a very clear and extremely important social aspect next to the supernatural dimension. This ceremony expressed the Church's concern to defend the rights and dignity of women in ancient society. ${ }^{14}$

\section{THE STATUS OR STATE OF VIRGINS AS A SEPARATE FORM OF CONSECRATED LIFE}

Secular virgins who received the consecration according to OCV belong to the state of virgins (ordo virginum) and form a separate form of consecrated life in the Church, also recognized by canon law. ${ }^{15}$ The expression "state" (ordo) is used here in the same sense as it had in the early Church, which meant "the structural category of the social and liturgical system of the Church." ${ }^{16}$. The state of virgins is therefore both an old and a new form of the Church, because it was reintroduced to the life of the Church, after eight centuries. ${ }^{17}$ This state is significantly different from all three other forms of consecrated life. Hence, consecrated virgins should not be identified with nuns, or members of any institution or association

RL 69 (1982) 4, 457-466; Klara, niepokalanka, Obrzędy profesji zakonnej i konsekracji dziewic, AK 380 (1972) 420-421.

${ }_{13}$ The names of the virgins were announced to all the people; Liber sanctorum Ecclesiae Romanae, PL 55, 129-130.

${ }^{14}$ More about the genesis and development of the ceremonies of consecration of virgins see priest Krzysztof Konecki, Konsekracja dziewic w odnowie liturgicznej Soboru Watykańskiego II, Włocławek 1997, pp. 37-87.

15 Vita consecrata, 7; CIC $604 \$ 1$. "The state of virgins belongs to the forms of consecrated life, they are expressing the holy intention to follow Christ more thoroughly - and they are consecrated to God by the diocesan bishop according to the approved liturgical ceremony, they are mystically married to Christ, the Son of God, and intended to serve the Church".

${ }^{16} \mathrm{R}$. De Tryon-Montalembert, Le renouveau conciliaire de la consécration des vierges, VC 6 (1981), 358.

${ }_{17}$ M. Schlosser, Alt-aber nicht veraltet. Die Jungfrauenweihe als Weg der Christusnachfolge, München 1992, pp. 33-36. 
of apostolic life, although they have many things in common with the latter ${ }^{18}$. The church did offer any institution for them. Hence, as in the first centuries of Christianity, they have a choice of different life forms: they can live separately, or in a family, they can organize or associate ${ }^{19}$ or live in a spiritual symbiosis with a religious institution, in order to provide themselves with greater spiritual help. Consecrated virgins living in the world and leading an individual life, outside the community, are not subject to any structures of community life. Therefore, they do not follow either the rule by which they are to live or they do not have any prioress to whom they would be subject. But although they lead a secular lifestyle, it is by no means a secular style. In addition, consecrated virgins do not experience their charisma of consecrated life through their founder, as it is in the case of the members of institutes of consecrated life. Their consecration, on a personal basis, takes place through the Church, represented in the person of the bishop who accepts the consecration. The state of virgins, which is the oldest form of consecrated life in the Church, has no other founder than the Church itself. ${ }^{20}$ Although virgins do not lead community life, this does not mean that they live without community. For virgins, this community is the Church in its constitutive structure, which is the diocese. The virgin's relationship with her local church is through a close relationship with her ordinary bishop. ${ }^{21}$ This particular type of spiritual communion of the consecrated virgin with her bishop, to whom she reports, determines the diocesan nature of the state of virgins. The relationship with the local Church is the proprium

${ }^{18}$ Cf. D. Pichard, Renouveau de la consécration des vierges, VS 128 (1974) $578-581$.

19 This organizing is not obligatory and does not mean shared housing. The freedom of association of consecrated virgins living in the world is confirmed by CPC/ KPK $604 \$ 2$, in which we read: "Virgins can associate/ organize themselves to fulfill their intentions and to serve the Church, corresponding to their own state and performed with the mutual assistance."

${ }^{20}$ La vergine consacrata nella Chiesa e nel mondo. Elementi di riflessione presentati all'attenzione dei Vescovi in vista del Sinodo sulla "Vita Consecrata"; testo italiano del documento elaborato dalle Vergini Consacrate riunite in convegno ad Alençon nell' agosto 1993, msp, 17; M.T. Huguet, La rénovation du rite liturgique de la consécration des vierges. Quelques questionnements etenjeux, "Nova et Vetera", 1992, 2, 108.

${ }^{21}$ Vita consecrata, 7. 
of this state and it largely determines that this form of consecrated life is different from the other three. ${ }^{22}$

\section{CONDITIONS FOR ADMITTING THE CONSECRATION}

The new Ordo clearly sets out the conditions for accepting the consecration. According to the contained provisions, the ceremony of consecration may admit or accept virgins living in the world who:

- "never married or lived in public, that is, openly, in a state contrary to purity or virginity." 23

This means that widows and women who have led in a public way, that is, an open lifestyle contrary to the virtue of chastity, cannot be consecrated. However, they can accept the consecration of women who are not virgins in a physical sense, i.e. those who have lost their virginity, but want to give God the promise of living in lifelong virginity, so that they can better devote themselves to God and the Church. The column which is extremely important - does not mention the concept of "physical virginity" as a necessary condition for the consecration. When accepting the consecration, the candidate's formal not material virginity is taken into account, the loss of material virginity does not reduce the meaning of it in any way. Although physical integrity is an objective value for a woman, it is only a sign of true virginity, which essentially consists in the integrity of the spirit and is expressed by total and faithful devotion to God. The consecration of Christian virginity is not about His consecration of physical and material impeccability and offering it to God, but first and foremost about dedicating the will to Him and about the desire to live in this state forever. ${ }^{24}$ This means that women who have lost their virginity in a guilty or culpable way may be accepted to the consecration, and through a vow of virginity they want to devote themselves completely to serve God and others. This applies to both women living privately in their

22 Cf. P. Moschetti, L' “Ordo virginum”. Un carisma nuovo e antico, ConSer 9 (1992) 21-22; G. Tosetti, La vita consacrata e la Chiesa locale, RPL 30 (1992) 3, 40-41.

23 OCV 5.

${ }^{24}$ A. Del Monte, Il senso della verginità cristiana. Riflessioni per un rito, Torino 1973, 53-55. 
homes and those affiliated to secular institutes. This is a very important decision, with important pastoral overtones brought by the new Ordo, which means a clear change in the current practice of the Church.

- "according to general opinion, by their age, prudence and customs they guarantee that they will persevere a clean or pure life which is devoted to serve the Church and neighbors." 25

Unlike the previous provision, which required the candidate to be 25 years old, Ordo does not specify the exact age that would predispose the virgin to receive the consecration. According to the current rule, personal maturity seems to be more important than the number of years, it guarantees that the obligations arising from the received act are consciously undertaken. Ordo leaves the decision in this matter to the bishop, who will personally decide to admit the consecration in each case individually.

- "were admitted to be consecrated by the ordinary bishop." 26

This and previous point, by clear emphasizing the significance and role of the ordinary bishop towards consecrated virgins living in the world, gives their calling the stigma of diocesan origin. While the charisma of virginity of nuns is lived within the life of the monastic community, this kind of virginity is lived within the life of the local Church, under the watchful eye of the bishop's fatherly care. In this current idea of the Church one should see a return to the very beginnings of the rites and to the original tradition of the Church, in which the source of the charisma of consecrated virginity of women living in the world has always been in due to the bishop and diocese. ${ }^{27}$

All the above requirements imposed on the candidates by the new Ordo emphasize the irreversibility characteristic of the consecration, if the virgin wants to be a sign of the Church, the faithful bride of Christ, in the same way as marriage is inseparable as the sacramental spousal unity of Christ and the Church. ${ }^{28}$

25 OCV 5.

${ }^{26}$ OCV 5.

27 R. De Tryon-Montalembert, Le renouveau conciliaire de la consécration des vierges, 362-363.

${ }^{28}$ G. Tosetti, Vergini consacrate nel mondo.Un ritorno alle origini, 59-60. 


\section{THE MINISTER OF THE RITE}

From the very beginning of the ceremony of the consecration of virgins, presiding over the rites, due to the nature of the betrothal, was reserved exclusively to the bishop. Therefore, so according to this centuries-old tradition of the Church, the bishop still remains the minister of the rite of virgin consecration. It should be noted, however, that in accordance with the spirit of the renewed liturgy of the rites of the consecration, his function as a minister is not purely ritual, i.e. it is not about giving the liturgy a greater degree of solemnity, but results from profound theological reasons, which primarily include the importance of virginity in the spiritual life of the Church. ${ }^{29}$

As a minister of rites, the bishop represents the Fatherhood of God and the virgin entrusts the vow of virginity in his hands. In this way he takes on the features of the sacrifice offered to God the Father, who, being the source of the grace of virginity, is also the purpose of the cult that the virgin wants to make to him by keeping her virginity. In turn, as a shepherd of the fold entrusted to him, by virtue of episcopal ordination, he represents Christ the Head and acts on His behalf ${ }^{30}$, and in relation to the Church, he represents Christ the Bridegroom. ${ }^{31}$ This last aspect of the bishop's function is emphasized in the formula accompanying placing of the ring on his hand during the episcopal liturgy: "take the ring, a sign of fidelity, the faith keeping, purity of life and protect the Church, the Bride of Christ". ${ }^{2}$ Therefore, the Bishop, who is the most complete sign of Christ the Bridegroom, is best suited to preside over the ceremonies of the consecration of virgins, who are "the image of the Church, the Bride of Christ." ${ }^{33}$

The function of a bishop, however, according to the new Ordo, is not only purely liturgical. In addition to conducting the ceremonies, the

29 P. Ruaro, Lordine delle vergini.I documenti, $i$ riti, le norme, iprincipi spirituali i pastorali, Torino 1990, 113.

${ }^{30}$ Cf. Lumen gentium, 23

31 P. Ruaro, Lordine delle vergini, 113.

32 Pontificale Romanum: De ordinatione diaconi, presbyteri et episcopi, Editio typica, Typis Polyglottis Vaticanis 1968, 75.

${ }^{33}$ OCV Dekret/ Decree. 
Church entrusts to him pastoral care for the consecrated virgins of his diocese. This applies to both the pre-consecration period and the time after consecration. One of the most important tasks of the bishop in the period preceding the consecration is to recognize the authenticity of the call of the candidates to live in virginity and to admit them to the consecration..$^{34}$ For this purpose, as well as to establish personal contact, the bishop should meet with the candidates and have a conversation with them on the appointed day preceding the consecration or at least on the eve. ${ }^{35}$ This meeting, however, should not have the nature of a legal questioning, but should be a pastoral conversation that takes place between the bishop as "father and pastor of the whole particular Church" and his spiritual daughter. According to Praenotand, the bishop's pastoral care extending to the post-consecration period should be expressed primarily in determining the manner in which virgins who lead secular life are obliged to preserve their virginity forever. In addition, he should watch over the manner and extent of virgins' multiple ministry to the Church and brothers, and look after their ongoing spiritual formation. The bishop's pastoral care is deeply rooted in the spiritual relationship that was born in the act of consecration between him and the virgin, because the virgin is the living image of the Church of which he is the bridegroom and the father. ${ }^{36}$

\section{TIME OF CONSECRATION}

Regarding the time of consecration, Ordo says: "it is appropriate that the consecration of virgins take place in Easter octave or during ceremonies, especially those related to the mystery of the Incarnation, on Sundays, on the Virgin Mary celebration day or on the virgins' celebration day"37 In so formulated recommendation regarding the exact selection of days, we see on the one hand a clear reference to the oldest practice of

${ }^{34}$ OCV Praenotanda 5.

${ }^{35}$ OCV 2.

${ }^{36} \mathrm{~T}$. Colombotti, I riti della professione religiosa e di consacrazione delle vergini, RPL 30 (1992) 3, 28.

37 OCV 1. 
the $\mathrm{Church}^{38}$, and on the other, a precise theological criterion, which is the bridal character of the mystery of Christ celebrated in those days. ${ }^{39}$ Therefore, the order in which the days are given does not refer to the liturgical degree, but to the theological significance of those days have for the ceremonies of consecration.

The celebration of the mystery of salvation on certain days of the liturgical year, measured by the rhythm of time, has its source in the Church's bridal love of Christ. The whole liturgical year is presented in this perspective by the Second Vatican Council: "Holy Mother Church considers it her duty to celebrate the redemptory work of her divine Bridegroom throughout the year on fixed days in venerable recollection." ${ }^{40}$

The current Ordo column mentions the Easter week first. The general norms and calendar of the liturgical year speak of the importance of these days. ${ }^{41}$ The above document emphasizes that Christ in a special way completed the redemption of mankind through the paschal mystery and at the same time accomplished the perfect worship of His Father. Thanks to this redemptory event the total renewal of a man occurred and the opportunity to re-enter the fullness of communion with God was restored because that is typically spousal community. The event of the paschal night is celebrated with the same intensity for the next fifty days, in particular during the paschal octave. Since the Passover of Christ is the celebration of the definitive union or betrothal of Christ with the Church, it is appropriate that on this day, through the consecration ceremony in

38 M. Righetti, Manuale di storia liturgica, vol. 4, Milano 1959, 490.

39 I.M. Calabuig, R. Barbieri, Consacrazione delle vergini, NDL, 301.

${ }^{40} \mathrm{KL} 103$.

41 "Because Christ accomplished the work of the redemption of people and the perfect adoration of God through the paschal mystery of His blessed Passion, through which, dying, He destroyed our death and by resurrection He brought us back to life, the holy Triduum of the Passion and Resurrection shines as the peak of the liturgical year. The same meaning or solemnity as Sunday has during the week has Easter during the liturgical year"; General norms of the liturgical year and calendar (henceforth ONRLiK), 18.

"Fifty days from the Resurrection Sunday to Pentecost Sunday are celebrated with great joy as one holiday, moreover, as «great Sunday»; ONRLiK 22.

"The first eight days of the Easter season are the Octave of Easter. They are celebrated as the Lord's solemnities"; ONRLiK 24. 
which the virgin is "raised to the dignity of Christ's bride" ${ }^{42}$, the church community receives a clear and legible sign of the final union or nuptials. ${ }^{43}$

Ceremonies that present the mystery of the Incarnation and Sundays are listed after the Easter octave. Because Sunday is a small Easter, the weekly anamnesis of the Risen Bridegroom, it also contains the same theological content of the marriage of Christ with the Church as the annual Passover. However, the days on which the mystery of the Incarnation is present are mentioned because it was in the mystery of the Incarnation that the marriage or betrothal of Christ with the Church began. ${ }^{44}$

Virgin Mary and holy virgins celebrations are mentioned at the end. Mary - because She, being the fullest expression of virgo sponsa Christi, is a model and almost hypostasis of the Church-Bride and an unparalleled model for the consecrated virgin. The virgins celebrations, however, because they experienced in an existential way, both in the dimension of their body and spirit, the Christ-Church nuptial event. ${ }^{45}$

The theological recommendation, read in the theological aspect, therefore prefers consecration on those solemnities and celebrations of the liturgical year that better express the mystery of the nuptials of Christ with the Church.

\section{A PLACE OF CONSECRATION}

Regarding the place of the liturgy of the consecration, Ordo expressly states that "the rite should take place in the cathedral church, unless local circumstances and customs speak against it." 46 This indication, like the indication concerning the minister of rites, should be seen primarily in the theological aspect, and not in the legal aspect.

The above recommendation first results from the theological importance of the temple as a place of worship. The solemn prayer said dur-

42 OCV 16.

${ }^{43}$ Cf. T. Colombotti, I riti della consacrazione delle vergini e della professione religiosa, Torino 1991, 69-70.

44 Ibidem 70-71.

45 I.M. Calabuig, R. Barbieri, Consacrazione delle vergini, 301.

${ }^{46}$ OCV 3. 
ing the church sacrifice rites draws attention to this: "This temple is a sign of the mystery of the Church, which Christ sanctified with His Blood to be His Bride, glorious Virgin shining in purity of faith and mother giving life by the power of the Holy Spirit." 47 The temple is therefore a sign of the mystery of the Church "chosen by Christ as the Bridegroom."

The place of consecration is also dictated by the function of the cathedral church in the spiritual life of the diocese. According to the Caeremoniale episcoporum, the episcopal cathedral is included in it, it is a sign of the teaching and authority of the shepherd of the local Church, as well as a sign of the unity of all those who profess this faith, which the bishop teaches as a shepherd of his fold." 48 That is why the cathedral is the "center of the liturgical life of the diocese" 49 , it is the church of the bishop and the symbol of his bride. In addition, the local church is especially visible in the cathedral, especially when the bishop presides over the Eucharist. ${ }^{50}$ The believers who participate in the rites of the consecration of virgins are not only their relatives and friends, but above all the people of God, built on the Eucharist around his shepherd, people who live and discover, also in the sign of a virgin devoted to God, their own baptismal calling. The whole consecration liturgy, together with its rich symbolism and euchological and biblical content, is a kind of catechesis on the importance of Christian life, understood as the spousal unity between Christ and the Church, which is the foundation for both the consecrated virgin and those living in the sacrament of matrimony.

47 Pontificale Romanum: Ordo dedicationis ecclesiae et altare, Editio typica, Typis Polyglottis Vaticanis 1977, 46.

${ }^{48}$ Ecclesia cathedralis ea est in qua Episcopi cathedra sita est, signum magisterii potestatisque pastoris Ecclesiae particularis necnon signum unitatis credentium in ea fide, quam Episcopus, tamquam gregis pastor, annuntiat; Caeremoniale episcoporum, ex decreto Sacrosancti Oecumenici Concilii Vaticani II instauratum auctoritate Ioannis Pauli pp. II promulgatum (henceforth CE), Editio typica, Typis Polyglottis Vaticanis 1984, 42.

49 Proinde ecclesia cathedralis centrum vitae liturgicae dioecesis merito haberi debet; CE 44.

50 Praecipua manifestatio Ecclesiae localis habetur quando Episcopus, ut sacerdos magnus sui gregis, Eucharistiam celebrat praesertim in ecclesia cathedrali, a suo presbyterio et ministris circumdatus, cum plenaria et actuosa participatione totius plebis sanctae Dei; CE 119. 
The very theological meaning of rites also demands that they be celebrated in the cathedral. The consecration of virgins is essentially a marriage or nuptials rite; a special locus for the mystical marriage of Christ with the Church, represented in this particular fact by a virgin who is sacrificing herself. During the consecration, the Christian virgin, by the power of the Holy Comforter, is praised to the dignity of the bride of Christ and connected with Him by an inseparable knot. ${ }^{51}$ By virtue of the irrevocable liturgical act of consecration, the close and spiritual relationship between the virgin and the bishop is formed, and thus between the diocese for which she now desires to sacrifice her spiritual strength.

Therefore, celebrating the rites of the consecration of virgins in the cathedral church, through the perfect convergence of the wedding symbols, aptly characterizes the rite itself, as an expression of the charisma given to the local church and as a marriage/nuptials rite between Christ - the Bridegroom and the Church-the Bride. ${ }^{52}$

\section{THE MAIN THEOLOGICAL ASSUMPTIONS OF CONSECRATION}

The woman's virginity, which is a great gift of God for her and a sign of a special choice, receives its proper meaning when it is consecrated during the liturgy. While until the time of consecration it remained a woman's personal matter, somehow private, but since the solemn act of consecration, carried out in the Church by the authority of the Holy Spirit, it takes on a social and ecclesiastical dimension. Consecration gives it a full Christian meaning and makes the consecrated virgin a living sign of reality and supernatural values. Theological analysis of the rites of the consecration of virgins authorizes us to pay attention to two the most characteristic and the most important theological aspects of the consecration of Christian virginity. They are the spousal and eschatological dimensions.

51 OVC 16.

52 T. Colombotti, Consacrazione delle vergini e professione religiosa. Due libri liturgici della Chiesa italiana, RL 69 (1982) 4, 451. 
The Christian Virgin, making her promise to God of lifelong virginity, "marries" Christ in a mystical way, becoming His bride forever. Her spiritual, perpetual and virgin covenant with Christ is the realization of Christ's spousal love for the Church. Since a consecrated woman marries her Bridegroom spiritually and without any human mediation, her spousal relationship, despite being outside the sacramental structure, illustrates better and more fully the mystery of Christ's love for the Church than it happens during the rite of marriage. In other words, the covenant of love between Christ and the virgin is already doing what the sacrament or rite of marriage means and announces. If marriage is a sacramental sign of Christ's spousal love for the Church, consecrated virgins surpass and transcend this sign quickly to achieve a sacred reality which the marriage is a symbol of. In this sense, we can speak of a certain superiority of the consecrated virginity over the traditional marriage. ${ }^{53}$

The eschatological dimension of consecrated virginity is due to single blessedness or celibacy for the kingdom of heaven. According to Christ's assurances, the eschatological kingdom will consist of single people (Mt 20,35). The consecrated virgin, choosing celibacy, a form of life appropriate for future times, anticipates these times and, in a way, makes them present here on the earth. It can be said that through her voluntary and conscious choice of living in a single blessedness for the kingdom of God, she testifies, to the present world, in a "physical" way (not only in terms of faith and spirit) of the arrival of a new heaven and a new earth (cf. Rev 21: 1). She also enjoys the privilege of being able to experience spiritually the real situation of the Church as such in relation to Christ, a situation which will be shared by every Christian during Parusia, when everyone will be united with Christ, in the same way that the Church , or the Bride, unites itself to Christ, his Bridegroom. Therefore, one can risk the claim that consecrated virgins are the visible sign of His mystery, in the life of the Church, they are the true epiphany of the Church, because they fully show its real face. They reveal to others what the Church is now and what all humanity must become. On their example, they show in a full way the essential nature of the Church, which, by the will of Christ Himself, is also the Virgin-Mother-Bride: „Virgin through intact faith,

53 A. Morta, Dinamica della castità consacrata, Roma 1969, 24. 
Bride through an inseparable relationship with Christ, Mother through numerous offspring." ${ }^{54}$ In this way, the consecrated virgin becomes a living sign of this future world, which is already present through faith and love, in which the sons of the resurrection „will neither marry nor bespouse” (Lk 20:35).

\section{DIOCESAN CHARACTER OF THE STATE OF VIRGINS}

The diocesan character of the state/ status of virgins has its deep roots in the very rite of consecration, which is always presided by the bishop, pastor and father of the diocese in which the virgin lives and works. Through his ministry, a spiritual relationship is born between her and the diocese, and thus with the entire universal Church. The person of the bishop fulfills here a constitutive function for the life of her status and for her special participation in the life of the local Church. However, this relationship is not incardinating, as is the case with a neoprebiter during his priestly order. The virgin's relationship with the diocese that came into being during the consecration is a special kind of spiritual bond with the local community of believers, which is expressed in her prayer and liturgical and apostolic life. It should be concluded that the consecrated virgin has the right to change the diocese and join the new local community. ${ }^{55}$ Such a change may be caused, for example, by her new place of residence or work. However, the bishop should be informed in advance of this intention, also because the service of the consecrated virgin will have to be accepted by another bishop.

Although the virgin's relationship with the diocese was formally born during the rite, its beginning is much earlier. It reaches the virgin's first meetings with her bishop, who, being her spiritual father and pastor of the diocese, has to recognize the authenticity of her virgin calling and her preparing for a spiritual marriage or betrothal with Christ. He also has the obligation to make the final decision regarding admission of the

54 OCV 16.

55 This results from the content of the following documents already cited in the work: Decretum, Praenotanda, Ordo, Kodeks prawa kanonicznego, Vita consecrate, which do not prohibit consecrated virgins to change their dioceses. 
candidate for consecration. ${ }^{56}$ For this purpose the bishop should meet with the candidate and have a conversation with her on the appointed day preceding the consecration or at least on the eve. ${ }^{57}$ This meeting, however, should not have the nature of a legal questioning, but should be a pastoral conversation between the diocese father and his spiritual daughter.

Speaking about the required communion of the virgin with her bishop and about her special references to his office, it should be noted that they are by no means optional or courtesy. Their existence is dictated by profound theological and pastoral reasons. They arise both from the function and role of the bishop as a shepherd, who is directing the local Church and who is responsible for the spiritual life of the local Church, as well as from the special place of the virgin among God's people, whose bishop is a shepherd.

The place of consecration also directly indicates the diocesan character of the state of virgins. Ordo makes it clear that the rite of the spiritual marriage of a virgin with her Divine Spouse should take place in the church of the diocese bishop, which is the cathedral temple, the mother of all churches in the diocese. ${ }^{58}$ The above remark, which is proper only to this form of consecrated life does not apply to, for example, religious profession, and has a deep theological justification. In addition to the many aspects mentioned above, the celebration of the rite in the cathedral, by virtue of its function, indicates the special relationship of the person receiving or admitting the consecration with her diocese, for which she would now sacrifice all her spiritual strength. Therefore, the possible apostolic, pastoral and charitable activities of the virgin, although carried out in specific parish communities, always have a diocesan reference and should be agreed, coordinated and confirmed by the bishop. Hence, after changes in the episcopal office, she should immediately introduce herself to the new shepherd to discuss with him the manner and the form of her ministry.

${ }^{56}$ OCV, Praenotanda 5c.

57 OCV 2.

${ }^{58}$ OCV 6. 
The direct dedication of lay virgins to the diocese's service is also indicated by the consecration prayer said by the bishop..$^{59}$ Next to many of the elements listed there, we find nothing that would be typical and appropriate for religious life, that is, community life, poverty and obedience.

However, it should be clearly emphasized here that the consecrated virgin is not a minister, but is an esse. Consecration is not a rite to set some ministry, but the inclusion of a virgin in the charismatic structure of the Church. The Virgin does not accept the consecration to "act" but to "be". It is a reality that has the value of presence. Its most important goal is to be a sign for the world and the environment which she lives in and works, this reality and these values that are out of this world, but which the world and all humanity expect. She also fulfills this function when she performs her professional and social work, which does not necessarily have to be directly related to the pastoral activity of the Church. This does not mean that the virgin should not perform a variety of tasks, very important and useful, consistent with her physiognomy of the consecrated woman, but they neither constitute her identity nor belong to the essence of her life status. Proprium of her life is to make transcendent reality in consecrated life present, and she is the physical carrier of this transcendental reality. It can therefore be said that her primary calling is to be a living sign of the supernatural reality for the world, while the whole activity is a consequence of it and flows from it. It can therefore be said that her primary calling is to be a living sign of the supernatural reality for the world, while all activity is a consequence of it and flows from it. Therefore, the apostolic activity of the virgin and all other things cannot be imposed, but only proposed to her. The multiple ministry of virgins is not the result of any legal obligations, but is the natural fruit of a call to follow Christ in perfect purity. The virgin should be left a wide range of freedom. There are a number of women who feel the calling to live in silence, prayer and contemplation, others, in turn, prefer to devote themselves to apostolic and charitable activities, while others are engaged in the field of social and professional life. However, the prayer and contemplation are primary and indispensable tasks for everyone so that they can remain faithful to the promises made and be clear signs of the future reality.

${ }^{59}$ OCV 24. 
The diocesan character of the state of virgins, expressed in a special spiritual relationship with the particular Church, is associated with the episcopal person and his office. A thorough analysis of both the headings and texts of the rite indicates the special tasks of the episcopal office towards the state of virgins. These tasks are completely different from those which the bishop has to fulfill towards lay believers, priests and even nuns; they are also different from the tasks and functions of a cleric manager because they only concern foro interno. Their specificity stems from the authentic spiritual connection between the bishop and the consecrated person and from the pastoral love with which he should receive and surround every charisma of consecrated life that benefits not only his local community but the entire Church.

\section{BIBLIOGRAPHY}

Jan Paweł II, List apostolski Mulieris dignitatem, AAS (1988) 1653-1729.

Jan Paweł II, Posynodalna adhortacja papieska Vita consecrata, AAS (1996) 377-486.

Acta et documenta Concilio Oecumenico Vaticano II apparando. Series I (Antepraeparatoria) I-XVI, Series II (Praeparatoria) I-VII, Typis Polyglottis Vaticanis 1960-1962; 1964-1969.

Acta synodalia Sacrosancti Concilii Oecumenici Vaticani II, I-XXVII, Typis Polyglottis Vaticanis 1973-1969.

Synod Biskupów. IX Zgromadzenie Zwyczajne, Życie zakonne i jego posłannictwo w Kościele i świecie. Lineamenta, Watykan 1992.

Synod Biskupów. IX Zgromadzenie Zwyczajne, Życie zakonne i jego posłannictwo w Kościele i świecie. Instrumentum laboris, Watykan 1994.

Obrzędy konsekracji dziewic, Katowice 1999.

Albrecht B., Jungfrauenweihe für Frauen, die in der Welt leben, "Ordenkorespondenz" 25 (1984) 298-305.

Augé M., La teologia della vita consacrata nei riti della consacrazione delle vergini e della professione religiosa, RPL 30 (1992) 3, 17-21.

Bolchi E.L., La consacrazione nell 'Ordo virginum. Forma di vita e disciplina canonica, Roma 2002.

Bugnini A., L' “Ordo consecrationis virginum”, OsRom 7-8 Settembre 1970, 1-4.

Bugnini A., La riforma liturgica (1948-1975), Roma 1983, 762-765.

Calabuig I.M., Barbieri R., Struttura e fonti dell "Ordo consecratio-nis virginum", w: Liturgia opera divina e umana, Roma 1982, 479-530.

Calabuig I.M., Barbieri R., Consacrazione delle vergini, NDL 294-314. 
Calabuig I.M., Barbieri R., Verginità consacrata nella Chiesa, NDL 1580-1599.

Calabuig I.M., La vergine consacrata vive e manifesta l'amore sponsale della Chiesa per Cristo, Roma 1995, msp (art. znajduje się w posiadaniu autora).

De Tryon-Montalembert R., Guerbert A., Lordre des vierges, VC 3/4 (1983) 227-229.

De Tryon-Montalembert R., La vierge consacrée signe de l'amour de l'Église pour le Christ, VC 4 (1989) 226-238.

De Tryon-Montalembert R., Consécration des vierges et hiérarchie, VC 4 (1989) 239-242.

De Tryon-Montalembert R., Le renouveau conciliaire de la consécration des vierges, VC 6 (1981), 358.

Enrica R., Del Cinque S., La vita consacrata e l'Ordo virginum nell' insegnamento di Paoli VI, "Istituto Paolo VI", notiziario n. 67 (2014) 69-85.

Kopeć J.J., Ruch liturgiczny, reforma i odnowa liturgiczna, RBL 4-5 (1985) 265-285.

Leclercq J., Vierge, virginité, DACL 15, 3094-3108.

Libera P., Duchowość dziewictwa konsekrowanego w świetle pism św. Ambrożego z Mediolanu, CT 64 (1994) 3, 87-99.

Nadolski B., Liturgika. Sakramenty, sakramentalia, błogosławieństwa, t. 3, Poznań 1992.

Nocent A., Il mistero di Cristo nella "Velatio sposae" e nalla "Velatio virginum", RL 55 (1968) 3, 368-377.

Nocent A., La consacrazione delle vergini, w: I sacramentali e le benedizioni, t. 7, Genova 1989, 9-29.

Recchi S., Lordine delle vergini, QDE 3 (1992) 141-150.

Recchi S., Valori qualificanti l'ordine delle vergini: oportunitŕ di un collegamento, w: Atti 4 e 5 Convegno dell' "Ordo Virginum", San Bonifacio 1993, 17-32.

Righetti M., Manuale di storia liturgica, t. 4, Milano 1959.

Ruaro P., Lordine delle vergini. I documenti, i riti, le norme, i principi spirituali e pastorali, Torino 1990.

Schlosser M., Alt - aber nicht veraltet. Die Jungfrauenweihe als Weg der Christusnachfolge, München 1992.

Stabińska J., Dziewictwo konsekrowane, Kraków 1990.

Szafraniec K., Konsekracja zakonna: sens i wartość, CT 54 (1984) 1, 37-44.

Tosetti G., Vergini consacrate nel mondo. Un ritorno alle origini, Bologna 1990.

Triacca A., Spirito Santo e liturgia. Linee metodologiche per un approfondimento, w: Miscellanea in onore di P. Cipriano Vagaggini, Roma 1980, 133-164.

Triacca A., Significato teologico-liturgico della "consacrazione cristiana" della verginità (Anámnesis - Epiclesis - Methexis), EL 96 (1982) 154-183. 